\title{
Redescription of Psolus tessellatus Koehler, 1896 (Echinodermata, Holothuroidea) with neotype designation
}

\author{
Claude MASSIN \\ Royal Belgian Institute of Natural Sciences, Department of Invertebrate Biology, \\ 29 rue Vautier, 1000 Brussels (Belgium), E-mail: claude.massin@naturalsciences.be \\ urn:1sid:zoobank.org:author:896580A2-73E2-4562-AFCD-6AA69E5125B4
}

\begin{abstract}
In the bycatch of a scientific campaign in the Bay of Biscay (VITAL 2002) a third specimen of Psolus tessellatus Koehler, 1896 was collected very close to the type locality. This specimen is here fully illustrated and designated as the neotype.
\end{abstract}

Key words. Psolidae, Bay of Biscay, redescription, first illustration, neotype.

Massin C. 2013. Redescription of Psolus tessellatus Koehler, 1896 (Echinodermata, Holothuroidea) with neotype designation. European Journal of Taxonomy 38: 1-5. http://dx.doi.org/10.5852/ejt.2013.38

\section{Introduction}

In 1895, the University of Lyon organized a campaign on board of the "Caudan" in the Bay of Biscay. During that expedition, material was collected between 110 and $1.710 \mathrm{~m}$ depth (Koehler 1896). Four new holothurian species were described and housed in the collections of the University of Lyon: Holothuria roulei Koehler, 1896 (= Mesothuria roulei (Koehler, 1896)), Paroriza pallens Koehler, 1896 (= Stichopus pallens (Koehler, 1896)), Benthogone rosea Koehler, 1896 and Psolus tessellatus Koehler, 1896. In 1985, Jangoux revisited the types in the collections of Lyon and only found the type material of Holothuria roulei and Benthogone rosea. The type material of Paroriza pallens and Psolus tessellatus was missing and must be considered as lost. Moreover, P. tessellatus was not illustrated by Koehler (1896).

A second catch of $P$. tessellatus was mentioned between the Azores and Madeira at $1.100 \mathrm{~m}$ depth by Fiege \& Janssen (1998), who first illustrated the species.

In 2002, IFREMER Nantes organized a campaign (VITAL) in the Bay of Biscay for the evaluation of fish populations. In the bycatch of trawled material one specimen of Psolus tessellatus was collected. It is the object of the present note.

\section{Material and methods}

The specimen of Psolus tessellatus was collected at Station 14 of the VITAL campaign ( $47^{\circ} 36^{\prime} \mathrm{N}-8^{\circ} 25^{\prime}$ W, 1399-1442 m, collecting date 23 Aug. 2002). It was fixed on a small stone (40 x 44 x $50 \mathrm{~mm}$ ) and housed in the collection of the RBINS under the catalogue number IG31016-HOL 1304. 


\title{
Abbreviations
}

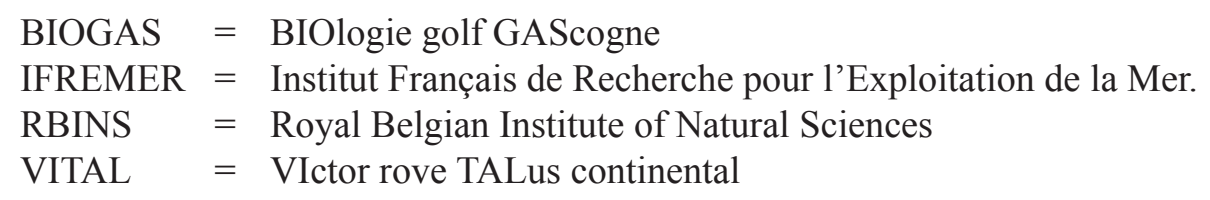

\section{Results}

\author{
Phylum Echinodermata Brugière, 1791 \\ Order Denrochirotida Grube, 1840 \\ Family Psolidae Forbes, 1841 \\ Genus Psolus Oken, 1815
}

Psolus tessellatus Koehler, 1896

Figs 1A-D, 2A-G

Psolus tessellatus Koehler, 1896: 119.

Psolus tessellatus - Mortensen 1927: 414. — Fiege \& Janssen 1998: 341, figs 2-3.

Psolus tesselatus - Costelloe et al. 2001: 348.

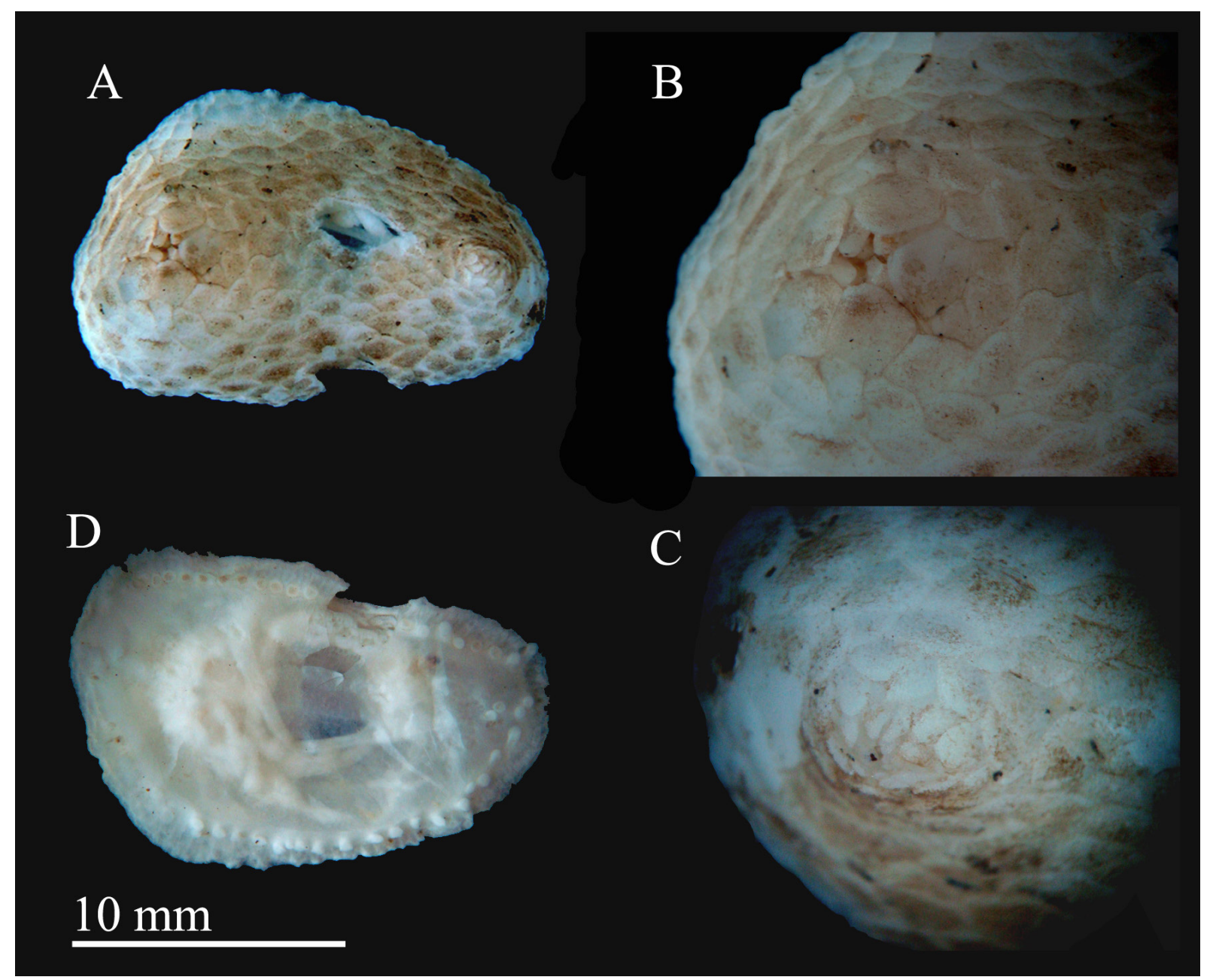

Fig. 1. Psolus tessellatus Koehler, 1896. A. Dorsal view. B. Buccal cone. C. Anal cone. D. Ventral view. 
MASSIN C., Psolus tessellatus, redescription, neotype

\section{Redescription}

Small oval specimen, $17.4 \mathrm{~mm}$ long, $10.6 \mathrm{~mm}$ broad and $2.4 \mathrm{~mm}$ thick (Fig. 1A). Dorsal body wall covered by large scales (from $850 \times 550$ to $1350 \times 1100 \mu \mathrm{m}$ ) (Figs 1A-C, 2A). The scale consists of one layer at the edge but rapidly becomes multilayered when going to the centre (Fig. 2B). No tube

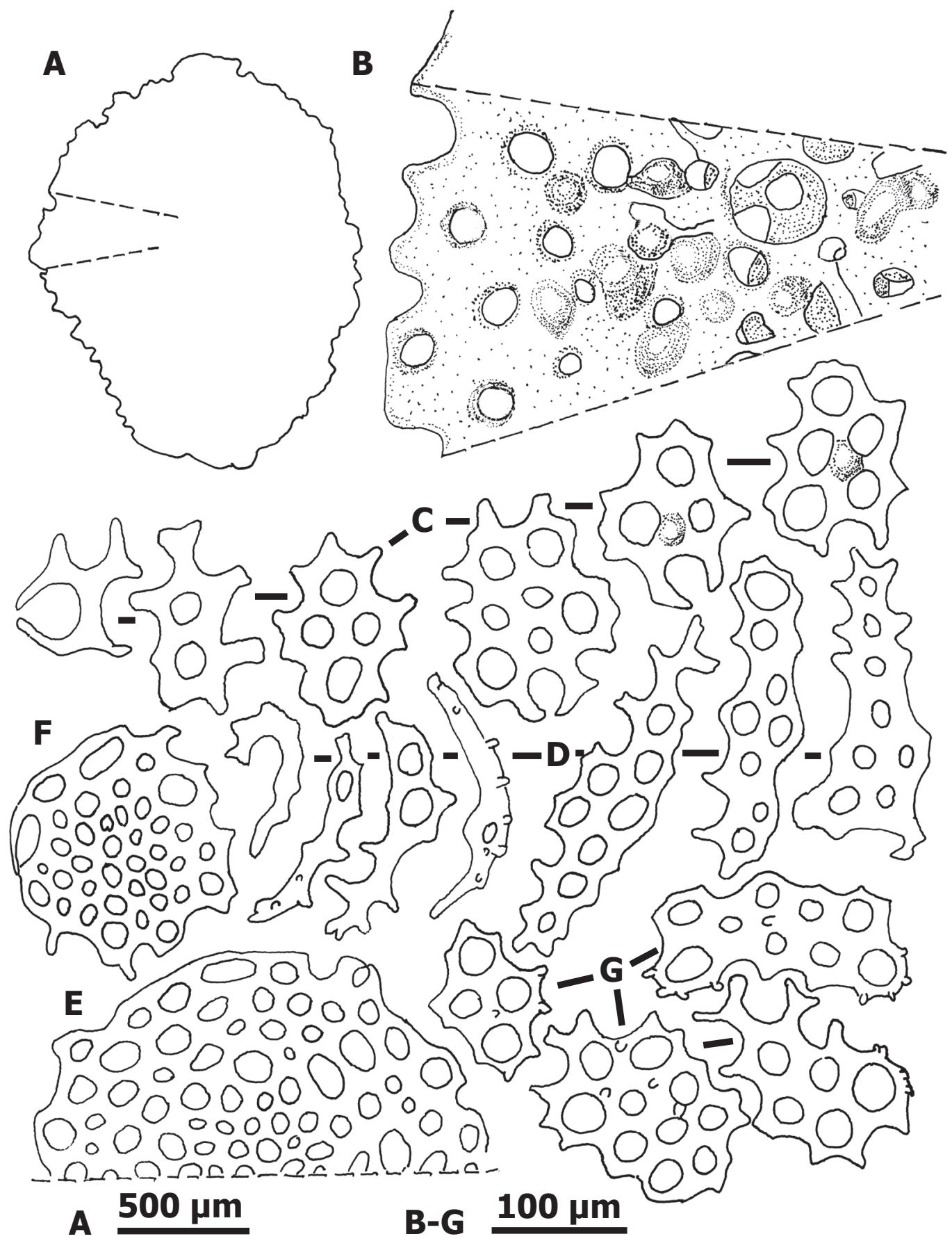

Fig. 2. Psolus tessellatus Koehler, 1896. A. Dorsal scale. B. Detail of dorsal scale. C. Plates of ventral sole. D. Rods of large tube feet. E. End plate of large tube feet. F. End plate of small tube feet. G. Perforated plates at the base of the large tube feet. 
feet dorsally. Ten scales between mouth and anus. Anus surrounded by irregular small plates (Fig. 1C). Mouth surrounded by 10 scales: five large triangular scales alternating with 5 small, elongated scales (Fig. 1A, B). Tentacles fully retracted, not observed.

Ventral sole very thin, translucent, calcareous ring and digestive tract visible by transparency (Fig. 1D). Ossicles as perforated plates, 100-160 $\mu \mathrm{m}$ long with 1-8 holes (Fig. 2C). Ventral sole with 2 rows of tube feet at the edge (Fig. 1D). Inner row of tube feet large, with perforated rods, 125-280 $\mu \mathrm{m}$ long (Fig. 2D) and large end plate in one piece (more or less $300 \mu \mathrm{m}$ across) (Fig. 2F). External row with very small tube feet with small end plates made of one piece (more or less $100 \mu \mathrm{m}$ across) (Fig. 2E). At the base of the large tube feet, perforated plates, $100-170 \mu \mathrm{m}$ long, similar to those of the ventral sole, sometimes knobbed (Fig. 2G). No mid ventral tube feet except 1-2 at the rear (Fig. 1D).

\section{Discussion}

The specimen at hand belongs without any doubt to the genus Psolus: thick dorsal surface covered by scales, thin ventral sole, tube feet restricted to the ventral sole. Only 7 Psolus species are known from the Northeast Atlantic Ocean, viz P. fabricii (Duben \& Koren, 1846), P. hypsinosus Heding, 1942, P. nummularis R. Perrier, 1899, P. phantapus (Strussenfeld, 1767), P. pourtalesi Théel, 1886, P. squamatus (Müller, 1776), and P. tessellatus Koehler, 1896.

P. tessellatus is readily separated from the other mentioned species by the valves surrounding the mouth: 5 large triangular ones alternating with 5 narrow ones. It is also the only Psolus species mentioned here with 10 scales present between mouth and anus. For P. hypsinosus and P. fabricii (see Heding 1942) there are only 5-7 scales between mouth and anus, whereas for P. pourtalesi, P. squamatus and $P$. nummularis (see Théel 1886; Deichmann 1930; Madsen \& Hansen 1994; Perrier 1902) there are over 15. P. tessellatus is also the only Psolus species present in the Bay of Biscay.

The species seems to have a very restricted distribution and bathymetry in the Bay of Biscay: $45^{\circ} 47^{\prime} \mathrm{N}$ $-6^{\circ} 15^{\prime} \mathrm{W}$ and $1.700 \mathrm{~m}$ for the holotype, and $47^{\circ} 36^{\prime} \mathrm{N}-8^{\circ} 25^{\prime} \mathrm{W}$ and $1.400 \mathrm{~m}$ for the present specimen. In deeper water (1900-4800 m) holothurians are abundant (34 species, Sibuet 1977) but P. tessellatus was not mentioned in spite of intensive sampling by IFREMER Brest (BIOGAS, Sibuet 1977; Sibuet \& Segonzac 1985). IFREMER Nantes has intensively sampled at depths of 0-500 $\mathrm{m}$ with a few samples at $1000 \mathrm{~m}$ (J. Martin, personal communication; Sea Cruises Inventory 2012), but no P. tessellatus were collected.

The rarity of $P$. tessellatus could be an artefact linked to the low intensity of sampling between 1.000 and $1.700 \mathrm{~m}$, a zone obviously favourable to the species (Fiege \& Janssen 1998).

Since the holotype is lost and Koehler (1896) did not give any illustrations of the holotype (general aspect and ossicles) and since the specimen studied here was collected very close to the type locality, it is here designated as the neotype of $P$. tessellatus (see International Code of Zoological Nomenclature, articles $75,75.3 .4,75.3 .6$.$) .$

\section{Acknowledgements}

It is a pleasure to thank Dr. Y. Samyn (RBINS) for comments on the first draft of this manuscript, Mme J. Martin (IFREMER Nantes) for allowing me to study material from the VITAL Campaign and Mr. A. Van Haelen for the photographs on Plate 1. 


\section{References}

Costelloe M., Emblow C. \& White R. 2001. European Register of Marine Species: a check-list of the marine species in Europe and a bibliography of guides to their identification. Patrimoines Naturels 50, Muséum National d'Histoire Naturelle, Paris.

Deichmann E. 1930. The holothurians of the western part of the Atlantic Ocean. Bulletin of the Museum of Comparative Zoology at Harvard College 71 (3): 41-226.

Fiege D. \& Janssen R. 1998. Ein Fall von Parasitismus bei Psolus tessellatus einer ungewöhnlichen Holothurie. Natur und Museum 128 (10): 341-344

Heding S.G. 1942. Holothuroidea II. The Danish Ingolf-Expedition IV (13): 1-39.

Jangoux M. 1985. Catalogue commenté des types d'Echinodermes actuels conservés dans les collections lyonnaises. Nouvelles Archives du Muséum d'Histoire naturelle de Lyon 23: 3-11.

Koehler R. 1896. Echinodermes. Résultats Scientifiques de la campagne du «Caudan» dans le golfe de Gascogne 1: 33-127.

Madsen F.J. \& Hansen B. 1994. Echinodermata Holothuroidea. Marine Invertebrates of Scandinavia 9, Scandinavian University Press, Norway.

Mortensen T.H. 1927. Handbook of the Echinoderms of the British Isles. Oxford University Press, London.

Perrier R. 1902. Holothuries. In: Perrier R. (ed.) Expéditions Scientifiques du «Travailleur» et du «Talisman»: 273-554. Masson, Paris.

Sea Cruises Inventory. 2012. http://www.ifremer.fr/sismer/UK/catal/campagne/indexorga2 armat. htql? corg=IFREM

Sibuet M. 1977. Répartition et diversité des Echinodermes (Holothurides-Astérides) en zone profonde dans le Golfe de Gascogne. Deep-Sea Research 24: 549-563.

Sibuet M. \& Segonzac M. 1985. Abondance et répartition de l'épifaune mégabenthique. In: Laubier L. \& Moniot C. (eds) Peuplements profonds du Golfe de Gascogne, campagne Biogas: 143-156. IFREMER, Brest.

Théel H. 1886. Reports on the Results of Dredging in the Gulf of Mexico (1877-78), in the Caribbean Sea (1879-80), and along the Eastern Coast of the United States during the Summer of 1880 by the U. S. Coast Survey Steamer "Blake". Bulletin of the Museum of Comparative Zoology at Harvard College $13(1): 1-21$.

Manuscript received: 5 December 2012

Manuscript accepted: 28 January 2013

Published on: 7 February 2013

Topic editor: Rudy Jocqué

Desk editor: Kristiaan Hoedemakers

Printed versions of all papers are also deposited in the libraries of the institutes that are members of the EJT consortium: Muséum National d'Histoire Naturelle, Paris, France; National Botanic Garden of Belgium, Meise, Belgium; Royal Museum for Central Africa, Tervuren, Belgium; Natural History Museum, London, United Kingdom; Royal Belgian Institute of Natural Sciences, Brussels, Belgium; Natural History Museum of Denmark, Copenhagen, Denmark. 